\title{
IMPACT OF FORTIFYING COW'S MILK WITH WHEY PROTEIN HYDROLYSATE ON YOGHURT QUALITY
}

\author{
K. M. K. Kebary, S. A. Husien, R. M. Badawi and M. A. M. Habib \\ Department of Dairy Sci. and Technol., Faculty of Agriculture, Menoufia University, \\ Shibin El-Kom, Egypt.
}

Received: Jun. 21,2020

Accepted: Jul. 4, 2020

\begin{abstract}
Quality attributes of yoghurt made from cow's milk fortified with whey protein hydrolysate were studied. Six yoghurt treatments were made, control yoghurt was made by adding $3 \%$ non-fat dry milk to cow's milk while the other five treatments were made by fortifying cow's milk by $0.5,1.0,1.5,2.0$ and $2.5 \%$ whey protein hydrolysate respectively and $3.0 \%$ nonfat dry milk to each treatment. All yoghurt treatment was stored in refrigerator for 12 days and was sampled when fresh and at 3, 6, 9 and 12 days for chemical, rheological, microbiological analysis and sensory evaluation. The obtained results indicated that adding whey protein hydrolysate to cow's milk caused a significant increase of total solids, total protein and ash contents, titratable acidity, while decreased $\mathrm{pH}$ values and whey syneresis of yoghurt treatments and these effects were proportional to the rate of adding whey protein hydrolysate. Also, adding whey protein hydrolysate up to $2.0 \%$ increased the scores of organoleptic properties and treatment T4 that made with adding $2.0 \%$ whey protein hydrolysate was the most acceptable yoghurt treatments. Total solids, total protein, ash and fat contents of all yoghurt treatments did not change significantly, $(P>0.05)$ during storage period, while titratable acidity increased. Whey separation decreased during storage period up to the sixth day of storage period then increased up to the end of storage period, while the scores of organoleptic properties were almost stable up to the ninth day of storage period.
\end{abstract}

Key words: Cow milk, non-fat dry milk, whey protein hydrolysate, yoghurt, syneresis, organoleptic properties.

\section{INTRODUCTION}

Yoghurt is the most popular fermented milk produced all over the world. Supplementing yoghurt with probiotic bacteria and prebiotics increased the health and nutritional benefits of yoghurt. Recently the production and consumption of yoghurt has been increased tremendously in Egypt. The nutritional importance of yoghurt is based not only on the nutritive value of the milk from which it is made and the chemical changes of milk components occurring during fermentation but also some beneficial effects such as prophylactic and healing (Birollo et al., 2000; Ayar et al., 2006; Chandan, 2006 and Shah, 2007).
There is large quantity of whey are produced during cheese making, whey was considered the most important pollutant of the dairy industry. Most of whey produced in Egypt was discharged directly into the sewage system, but according to the Egyptian environmental low that was issued recently, dairy effluents should be treated before its drainage into the sewage system. Therefore, recovery of whey proteins which represent $20 \%$ of milk proteins can be very important. Whey protein products have been used in the manufacture of many dairy and nondairy products because of their valuable health and technological benefits. Whey protein can be used as an emulsifying, thickening, gelation, foaming, and water binding 
agent resulting in manufactured products with similar and desired characteristics compared to those produced with classical ingredients.

In view of a for mentioned the objective of this study were to investigate the possibility of making a good quality yoghurt that made from cow's milk using whey protein hydrolysate and monitor the changes of chemical, microbiological and organoleptic properties during cold storage.

\section{MATERIALS AND METHODS}

\section{Bacterial strains}

Active Streptococcus thermophilus
(EMCC 1043) and Lactobacillus
delbrueckii subsp. bulgaricus (EMCC
1102) were obtained from Cairo Mircen,
Ain Shams University, Egypt.
Lactobacillus delbrueckii subsp.
bulgaricus and Streptococcus
thermophilus were activated individually
by three successive transfers in sterile
10\% reconstituted non-fat dry milk.

\section{Manufacture of yoghurt}

Fresh cow's milk was standardized to 3\% fat. The preliminary experiment showed that the best yoghurt quality was made by supplementing cow's milk with 3.0\% nonfat dry milk. Standardized (3.0\% fat) cow's milk was fortified with $3.0 \%$ non-fat dry milk. This milk was divided into 6 treatments. These treatments were fortified with $0.0,0.5,1.0,1.5,2.0$ and 2.5 $\%$ whey protein hydrolysate (C, T1, T2, T3, T4, and T5, respectively). Non-fat dry milk (Dairy America, California, USA) and whey protein hydrolysate (Arla Food Ingredients, Skander, Denmark) were added to milk and stirred thoroughly, then filtered through cheesecloth. All milk batches were heated to $85^{\circ} \mathrm{C}$ for $20 \mathrm{~min}$, then cooled to $42^{\circ} \mathrm{C}$ and inoculated with $1.5 \%$ Streptococcus thermophilus and $1.5 \%$ Lactobacillus delbrueckii subsp.bulgaricus. The inoculated batches were packed in plastic cups and incubated at $42^{\circ} \mathrm{C}$ until complete coagulation. All yoghurt treatments were stored in a refrigerator $\left(6^{\circ} \mathrm{C} \pm 1\right)$ for 12 days and were sampled when fresh and at 3,6 , 9 and 12 days for chemical, microbiological, rheological analysis and sensory evaluation. The whole experiment was triplicated.

\section{Microbiological analysis:}

The total bacterial counts were determined using standard plate count agar (Marth, 1978). Streptococci were enumerated on yeast lactose agar medium (Skinner and Quensel, 1978). Lactobacilli were determined using MRS agar medium (De man et al., 1960). Moulds and yeasts were enumerated on Potato Dextrose agar (acidified) medium (Difco, 1953).

\section{Chemical analysis:}

$\mathrm{pH}$ value, titratable acidity and fat content were determined according to Ling (1963), while total solids, ash and total protein were determined according to A. O. A. C (2012).

\section{Rheological properties:}

Synerasis was determined according to the method of Danneberg and Kessler (1988) with slight modification. One hundred grams of yoghurt in plastic cup were cut into four sections and transferred into funnel fitted with 120 mesh metal screen. The amount of whey drained into a graduated cylinder was measured after $120 \mathrm{~min}$. at room temperature $\left(20 \pm 1^{\circ} \mathrm{C}\right)$ for all yoghurt treatments stored for $1,3,6,9$ and 12 days.

Textural parameters are determined using Texture Analyzer TMS-Pro (Food Technology Corporation, sterling, Virginia, USA). equipped with (250lbf) load cell and connected to a computer programmed with $\mathrm{Pro}^{\mathrm{TM}}$ texture analysis 
software (program, DEV TPA withhold). The texture of yoghurt samples was evaluated in triplicate of each batch of a set yoghurt sample prepared in a 100-ml cup at a temperature of $4^{\circ} \mathrm{C}$. A flat rod probe was subjected to two subsequent cycles (bites) of compressiondecompression. The probe used in "Texture Profile Analysis" (TPA) was $49.95 \mathrm{~mm}$. diameter, double compression test to penetrate $50 \%$ depth, at speed of 1 $\mathrm{mm} / \mathrm{s}$ and of penetration using cycle or hold programs. Data were collected on computer and the texture profile parameters were calculated from LFRA texture analyzer and computer interface. Calculation described by Bourne (2003) was used to obtain the texture profile parameters. The parameters stimulating included hardness (measure of force required to achieve a given deformation), adhesiveness (the work necessary to overcome the attractive forces between the surface of a food and surface of other materials with which it comes in contact, e.g., the teeth, palate and tongue, cohesiveness (a measure of strength of internal bonds making up the body of the product), springiness (a measure of the rate at which a deformed material returns to its original dimensions after the deforming force is removed), chewiness (the energy required to masticate a solid food material to a state ready for swallowing) and guminess (the energy required to disintegrate a semi-solid food to a state ready for swallowing) (Fox et al., 2017).

\section{Sensory evaluation:}

Yoghurt was judged by ten panelists from the staff members of Dairy Science and Technology Department, and Food Science and Technology Department, Faculty of Agriculture, Menoufia University. Results were recorded on a score sheet described by (Kebary and Hussein, 1999).

\section{Statical analysis:}

Data were analyzed using completely randomized block design and $2 \times 3$ factorial design. Newman-Keuls test was used to make the multiple comparisons (Steel and Torrie, 1980) using Costat program. Significant differences were determined at $p \leq 0.05$.

\section{RESULTS AND DISCUSSION}

The obtained results indicated that the titratable acidity of yoghurt treatments increased by adding whey protein hydrolysate and this increase was proportional to the rate of adding whey protein hydrolysate (Tables 1,5$)$. These results might be due to the stimulating effect of whey protein hydrolysate on the growth of lactic acid bacteria and consequently the development of acidity of yoghurt treatments (Gaudreau et al., 2013; Zhao and Shah, 2014 and Muniandy et al., 2016).

Titratable acidity of all yoghurt treatments increased significantly $(P \leq$ $0.05)$ as storage period progressed (Tables 1, 5). These results are in accordance with those reported by Delikanli and Ozcan (2014); Elkot (2017); Al-Aswad et al. (2018) and Blassy and Abdeldaiem (2018).

$\mathrm{pH}$ values of yoghurt treatments decreased by adding whey protein hydrolysate (Tables 1,5$)$. There was negative correlation between $\mathrm{pH}$ values and the rate of adding whey protein hydrolysate. These results might be due to enhancing the growth of lactic acid bacteria and consequently reducing the $\mathrm{pH}$ values of the resultant yoghurt treatments (Delikanli and Ozcan, 2014). pH values of all yoghurt treatments decreased throughout the storage period. Samples after 12 days had the lowest $\mathrm{pH}$ value and were significantly $(p \leq 0.05)$ different from samples at any storage period. Similar results are obtained by Delikanli and Ozcan (2014); Elkot (2017); Khalil and Blassy (2017); Al-Aswad et al. (2018) and Blassy and Abdeldaiem (2018). 
K. M. K. Kebary, et al.,

\begin{tabular}{|c|c|c|c|c|c|c|c|c|c|}
\hline \multirow{5}{*}{ 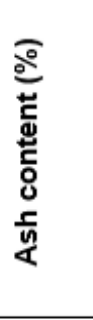 } & \multirow{5}{*}{ 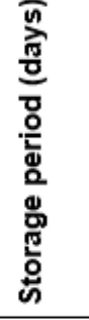 } & พ & œ & @ & ळ & த. & $\stackrel{\mathscr{g}}{\circ}$ & 兽 & 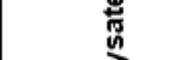 \\
\hline & & 0 & ֻ & 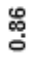 & $\overbrace{0}^{\circ}$ & ช్. & 壵 & \%̆ & 흠 \\
\hline & & 0 & $\stackrel{\circ}{\circ}$ & ๕: & 喿 & סू. & 号 & \%̆丶 & $\vec{\jmath}$ \\
\hline & & $m$ & $\stackrel{\leftrightarrow}{\circ}$ & 哭 & œ & స్ㅇ & ग़े & : & 。ัّ \\
\hline & & - & 总 & 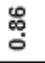 & 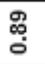 & ช్ & 号 & \%̊ㅇㅁ & $\stackrel{2}{2}$ \\
\hline ๖ & & 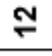 & $\stackrel{\circ}{\dot{m}}$ & $\stackrel{\text { ji }}{\dot{m}}$ & $\bar{j}$ & $\stackrel{\dot{m}}{\circ}$ & $\stackrel{\dot{m}}{\dot{m}}$ & $\stackrel{\rho}{\dot{m}}$ & \\
\hline 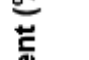 & $\frac{0}{2}$ & 0 & $\bar{m}$ & ले & ले & $\bar{m}$ & $\stackrel{\dot{m}}{\circ}$ & $\bar{m}$ & \\
\hline 气̆ & ఏ & 0 & iे & iे & $\bar{m}$ & $\stackrel{\rho}{\dot{m}}$ & $\bar{j}$ & $\stackrel{\rho}{j}$ & \\
\hline 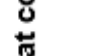 & $\frac{2}{2}$ & $m$ & 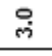 & $\stackrel{\text { ji }}{\dot{m}}$ & $\bar{j}$ & $\stackrel{\dot{m}}{\circ}$ & $\stackrel{\dot{m}}{\dot{m}}$ & $\bar{j}$ & ŏ \\
\hline & & - & $\bar{j}$ & 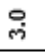 & $\bar{m}$ & $\stackrel{\text { mे }}{\dot{m}}$ & $\bar{j}$ & $\stackrel{\circ}{m}$ & 1 \\
\hline & 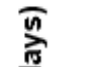 & $\stackrel{\Upsilon}{\leftarrow}$ & 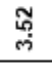 & ळ్ & $\stackrel{\circ}{\square}$ & 荌 & $\stackrel{\circ}{\%}$ & 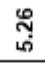 & \\
\hline કั & $\frac{0}{0}$ & $\sigma$ & 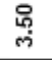 & 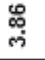 & $\overline{7}$ & $\stackrel{g}{q}$ & क्ष్ & స్ & \\
\hline ฐ & ฮั & 0 & 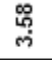 & 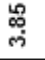 & $\stackrel{\frac{j}{d}}{\dot{q}}$ & 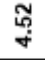 & $\stackrel{\circ}{\leftarrow}$ & స્ત & \\
\hline$\frac{2}{\sqrt{5}}$ & gั & m & 哭 & ఝ్ల & $\stackrel{0}{+}$ & 萬 & $\stackrel{\leftrightarrow}{+}$ & జ్రి & E \\
\hline & ڤั & $r$ & 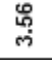 & ळ్ల & $\stackrel{0}{+}$ & $\stackrel{5}{+}$ & 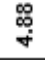 & 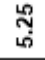 & \\
\hline ఏ & & $\stackrel{N}{\sim}$ & लू & 总 & 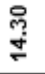 & $\stackrel{0}{+}$ & 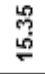 & : & \\
\hline $\begin{array}{l}\text { 苞 } \\
\mathbf{g}\end{array}$ & $\frac{\pi}{0}$ & $\sigma$ & 惢 & ח్ֶ & 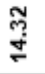 & 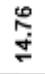 & 总 & $\begin{array}{l}\hat{0} \\
\stackrel{0}{\circ}\end{array}$ & \\
\hline $\begin{array}{l}8 \\
0 \\
y\end{array}$ & 읋 & 0 & 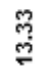 & 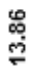 & 商 & 象 & 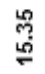 & 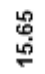 & \\
\hline$\frac{\bar{c}}{\bar{n}}$ & 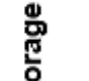 & $m$ & लू & ๓ & 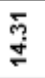 & 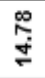 & 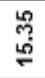 & $\begin{array}{l}\stackrel{\leftrightarrow}{\circ} \\
\stackrel{\leftrightarrow}{\circ}\end{array}$ & 总蒙 \\
\hline 음 & й & $r$ & लू & 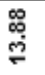 & 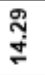 & $\begin{array}{l}\stackrel{\infty}{+} \\
\dot{+}\end{array}$ & 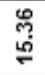 & $\begin{array}{l}0 \\
\stackrel{0}{\circ} \\
\stackrel{\leftrightarrow}{\sigma}\end{array}$ & 종 \\
\hline & 高 & 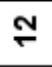 & 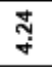 & $\stackrel{\text { พั }}{+}$ & m & $\bar{q}$ & สุ & ণิ & 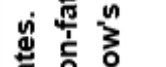 \\
\hline$\stackrel{n}{g}$ & $\frac{\pi}{0}$ & 0 & $\stackrel{f}{q}$ & $\underset{q}{q}$ & ঙ্ & $\underset{m}{\stackrel{m}{q}}$ & क्षे & $\underset{\text { Ț }}{\text { d }}$ & $\frac{0}{0}$ \\
\hline$\stackrel{\frac{1}{50}}{2}$ & 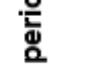 & 0 & 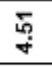 & $\stackrel{\circ}{\dot{q}}$ & 官 & $\underset{f}{q}$ & $\underset{f}{q}$ & $\frac{9}{q}$ & 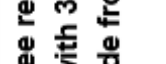 \\
\hline I⿳亠口冋口𧘇 & 通 & $m$ & $\stackrel{9}{i}$ & 总 & 品 & 志 & $\stackrel{\circ}{\dot{q}}$ & $\stackrel{\varphi}{q}$ & 胥它 \\
\hline & ڤั & $r$ & $\underset{+}{\overline{+}}$ & $\underset{+}{\Sigma}$ & $\stackrel{\because}{\leftrightarrow}$ & $\stackrel{\mathscr{8}}{+}$ & 荌 & 菅 & 施 \\
\hline ఏ & $\bar{n}_{\bar{\pi}}^{\bar{n}}$ & $\stackrel{N}{\sim}$ & $\stackrel{\infty}{=}$ & ণ్రి & 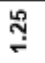 & $\stackrel{\text { ঙ্ }}{\sim}$ & $\bar{m}$ & 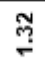 & 峁点 \\
\hline 胥 & 음 & $\sigma$ & $\stackrel{\Gamma}{亡}$ & 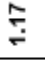 & ঙָ̆ & 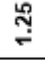 & ঙุ & $\stackrel{\text { m}}{+}$ & 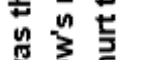 \\
\hline & 空 & 0 & $\stackrel{5}{\leftrightarrow}$ & 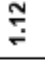 & $\stackrel{F}{+}$ & $\stackrel{\bar{y}}{\dddot{T}}$ & 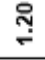 & $\underset{ָ}{ָ}$ & $\begin{array}{ll}5 & 0 \\
0 & 0\end{array}$ \\
\hline 量 & 章 & $m$ & 。ू & 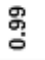 & $\stackrel{\mathscr{\rho}}{\leftarrow}$ & 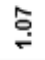 & $\stackrel{F}{=}$ & $\stackrel{m}{\rightleftarrows}$ & 可 은 \\
\hline 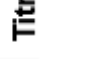 & 离 & - & த্ণু & 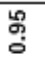 & 今̊ & $\stackrel{\sim}{\leftarrow}$ & $\stackrel{\circ}{\circ}$ & 㝏 & 我 \\
\hline 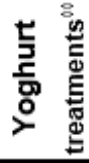 & & & U & $F$ & $\mathfrak{F}$ & 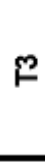 & $\stackrel{\mathbb{F}}{\leftarrow}$ & $\stackrel{\wp}{\vdash}$ & 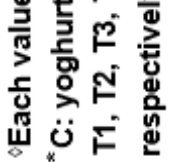 \\
\hline
\end{tabular}


There were significant differences $(P \leq$ 0.05 ) among yoghurt treatments in total solids content, (Tables 1,5$)$, which means adding whey protein hydrolysate caused a significant $(P \leq 0.05)$ increase in total solids content of the resultant yoghurt treatments (Tables 1,5). There was positive correlation between total solids content of yoghurt treatments and the rate of adding whey protein hydrolysate. These results are in agreement with those reported by Shamsia (2010); Unal and Akalin (2013); Wang et al. (2015) and Bierzuńska and Sokolińska (2018). On the other hand total solids content of all yoghurt treatments did not change significantly $(P>0.05)$ throughout the cold storage period (Tables 1,5$)$. These results are in agreement with those reported by Hamed et al. (2010); Kamaly et al. (2011); Kebary et al. (2012) and Ali et al. (2014).

The obtained results indicated that fortifying cow's milk with whey protein hydrolysate increased $(P \leq 0.05)$ the total protein of the resultant yoghurt treatments and this increase was proportional to the rate of adding whey protein hydrolysate (Tables 1,5$)$ (Singh, 2007; Shamsia, (2010); Unal and Akalin, 2013; Delikanli and Ozcan, 2014; Ali et al., 2014 and Bierzuńska and Sokolińska, 2018). Yoghurt treatment T5 contained the highest protein content and was significantly $(P \leq 0.05)$ different from other yoghurt treatments. These results could be attributed to the higher protein content $(\geq 76.0 \%)$ of whey protein hydrolysate. Total protein content of all yoghurt treatments did not change significantly ( $p$ $>0.05$ ) as storage period advanced (Table $1,5)$.Similar results were reported by AlAswad et al. (2018) and Blassy and Abdeldaiem (2018). Yoghurt treatments were not significantly $(P>0.05)$ different from each other in fat content, which means that adding whey protein hydrolysate did not have significant $(P>$ 0.05) effect on the fat content of the resultant yoghurt treatments (Tables 1,5) (Shamsia, 2010 and Ali et al., 2014). On the other hand, fat content of all yoghurt treatments did not change significantly ( $p$ $>0.05$ ) as storage period progressed
(Table1,5).These results are in agreement with those reported by Kebary et al. (2012); Ali et al. (2014); Al-aswad et al. (2018) and Blassy and Abdeldaiem (2018).

It could be observed that fortification of yoghurt made from cow's milk with whey protein hydrolysate caused a slight ( $p \leq$ 0.05 ) increased in ash content of the resultant yoghurt treatments (Tables 1,5$)$. On the other hand, all yoghurt treatments did not change significantly $(p \geq 0.05)$ during storage period (Tables 1,5$)$. These results are in agreement with those reported by Kamaly et al. (2011); Kebary et al. (2012) and Ali et al. (2014).

Hardness, adhesiveness, cohesiveness, springiness, gumminess and chewiness values of yoghurt samples fortified with whey protein hydrolysate are shown in Table (2). Fortification of yoghurt treatments with whey protein hydrolysate increased hardness, adhesiveness, cohesiveness, springiness, gumminess and chewiness . This increase was proportional to the rate of fortification (Tables 2, 5). It has been reported that incorporating of whey proteins improved the physical, textural and rheological properties of yoghurt (Megenis et al., 2006; Aziznia et al., 2008 and Landge, 2009).

Fortification of yoghurt made from cow's milk with whey protein hydrolysate caused a significant reduction $(p \leq 0.05)$ of whey syneresis $($ Tables 3,5$)$. There was a negative correlation between the rate of fortification and whey syneresis. These results could be attributed to the increase of total solids content as a result of fortifying cow's milk with whey protein hydrolysate (Hamed et al., 2010; ElKot, 2017 and Khalil and Blassy, 2017), addition of whey protein hydrolysate may lead to form a complex with casein micelles and prevent them from excessive fussion and form a fine meshed gel network which is less susceptible to whey separation and lor increasing the water holding capacity (Danneberg and Kessler, 1988; Pintro et al., 2011; Delikanli and Ozcan, 2014; Jeewanthi et al., 2015 and Ghanimah, 2018). The obtained results 
indicated that whey separation from all yoghurt treatments decreased as storage period progressed and reached their lowest value at the sixth day of storage period then increased gradually up to the end of storage period (tables 3,5), which might be due to the development of acidity. Similar trends were obtained by Kamaly et al. (2011); Kebary et al. (2012); khalil and Blassy (2017) and Blassy and Abdeldaiem (2018).

Total bacterial, Streptococci and Lactobacilli counts of yoghurt treatments made from cow's milk fortified with whey protein hydrolysate are presented in Table (3). Fortification of yoghurt treatments with whey protein hydrolysate increased the total bacterial, Streptococci and Lactobacilli counts and this increase was proportional to the rate of adding whey protein hydrolysate. These results could be attributed to the enhancement effect of whey protein hydrolesate on the growth of bacteria (Kailasapathy and Supriadi, 1996; Gaudreau et al., 2013 and Muniandy et al., 2016). Total bacterial, Streptococci and Lactobacilli counts increased until the third day of storage period then decreased up to the end of storage period which might be due to the development of acidity and cold storage. These results are in agreement with those reported by Badawi et al. (2008); Hamed et al. (2010) and Kebary et al. (2010).

Mould and yeast counts of yoghurt treatments made from cow's milk fortified with whey protein hydrolysate are shown in Table (3). It could be observed that yoghurt treatments were free from moulds and yeasts during the first nine days of storage period. After that, they appeared towards the end of storage period. These results are in agreement with those reported by Mehriz et al. (1993); Hamed et al. (2010) and Priyadarshani and Muthumuniarachchi (2018).

Scores of organoleptic properties (flavour, body and texture, acidity and appearance) of yoghurt treatments fortified with whey protein hydrolysate are presented in Table (4). There were significant $(p \leq 0.05)$ differences among yoghurt treatments of the scores of flavour, body \&texture and appearance (Table 4). Scores of organoleptic properties increased by increasing the rate of adding whey protein hydrolysate up to $2.0 \%$ (Tables 4,5 ), while increasing the rate of adding whey protein hydrolysate above that caused a significant decrease of the scores of organoleptic properties. These results agreed with the result of texture profile where adding whey protein hydrolysate improved the texture of the resultant yoghurt treatments. It has been reported that incorporating of whey proteins improved the texture and sensory quality of yoghurt (Megenis et al., 2006; Sodini et al., 2005; Guggisberg et al., 2007; Aziznia et al., 2008 and Landge, 2009). Yoghurt treatment (T4) that made by adding $2.0 \%$ whey protein hydrolysate gained the highest score of organoleptic properties and was significantly different from other yoghurt treatments .On the other hand scores of organoleptic properties of all yoghurt treatments did not change significantly during the first nine days of storage period (ElKot, 2017; Khalil and Blassy, 2017; Al-Aswad et al., 2018 and Blassy and Abdeldaiem, 2018).

Table (2): Textural parameters of yoghurt fortified with whey protein hydrolysate

\begin{tabular}{|c|c|c|c|c|c|c|c|}
\hline $\begin{array}{c}\text { Yoghurt } \\
\text { treatments }^{\circ}\end{array}$ & $\begin{array}{c}\text { Fracture } \\
(\mathrm{N})\end{array}$ & $\begin{array}{c}\text { Hardness } \\
(\mathrm{N})\end{array}$ & $\begin{array}{c}\text { Adhesiveness } \\
(\mathrm{mj})\end{array}$ & $\begin{array}{c}\text { Cohesiveness } \\
(\text { Ratio })\end{array}$ & $\begin{array}{c}\text { Springiness } \\
(\mathrm{mm})\end{array}$ & $\begin{array}{c}\text { Gumminess } \\
(\mathrm{N})\end{array}$ & $\begin{array}{c}\text { Chewiness } \\
(\mathrm{mj})\end{array}$ \\
\hline C $^{*}$ & $6.7^{\mathrm{d}}$ & $6.7^{\mathrm{d}}$ & $2.337^{\mathrm{f}}$ & $0.42^{\mathrm{d}}$ & $11.29^{\mathrm{d}}$ & $2.1^{\mathrm{d}}$ & $34.34^{\mathrm{f}}$ \\
\hline T1 & $7.6^{\mathrm{cd}}$ & $7.6^{\mathrm{d}}$ & $3.143^{\mathrm{e}}$ & $0.46^{\mathrm{cd}}$ & $13.07^{\mathrm{cd}}$ & $2.9^{\mathrm{c}}$ & $55.74^{\mathrm{e}}$ \\
\hline T2 & $8.9^{\mathrm{c}}$ & $8.9^{\mathrm{d}}$ & $5.246^{\mathrm{d}}$ & $0.52^{\mathrm{bc}}$ & $14.21^{\mathrm{c}}$ & $3.5^{\mathrm{c}}$ & $60.61^{\mathrm{d}}$ \\
\hline T3 & $11.2^{\mathrm{b}}$ & $11.2^{\mathrm{c}}$ & $5.369^{\mathrm{c}}$ & $0.53^{\mathrm{bc}}$ & $16.47^{\mathrm{b}}$ & $4.3^{\mathrm{b}}$ & $84.10^{\mathrm{c}}$ \\
\hline T4 & $13.7^{\mathrm{a}}$ & $13.9^{\mathrm{b}}$ & $6.470^{\mathrm{b}}$ & $0.55^{\mathrm{b}}$ & $18.49^{\mathrm{a}}$ & $4.8^{\mathrm{b}}$ & $93.1^{\mathrm{b}}$ \\
\hline T5 & $14.4^{\mathrm{a}}$ & $15.9^{\mathrm{a}}$ & $10.338^{\mathrm{a}}$ & $0.67^{\mathrm{a}}$ & $19.50^{\mathrm{a}}$ & $6.4^{\mathrm{a}}$ & $125.47^{\mathrm{a}}$ \\
\hline
\end{tabular}

${ }^{0}$ Each value in the table was the mean of three replicates.

* see Table (1)

a, b different letters in the same column means the treatment are significantly different.

Significant at 0.05 level (0.05). 


\begin{tabular}{|c|c|c|c|c|c|c|c|c|}
\hline \multirow{5}{*}{ 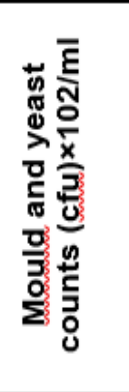 } & \multirow{5}{*}{ 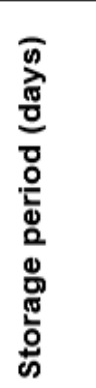 } & $\stackrel{N}{\sim}$ & $\stackrel{N}{\simeq}$ & $\stackrel{\infty}{\sim}$ & నิ & $\bar{N}$ & $\stackrel{\widetilde{N}}{\mathcal{N}}$ & 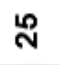 \\
\hline & & 0 & 口 & Q & 只 & z & z & Q \\
\hline & & 0 & z & Q & Q & q & $\underline{z}$ & $\mathrm{Q}$ \\
\hline & & $m$ & 只 & 只 & q & z & $\mathrm{q}$ & $\mathrm{q}$ \\
\hline & & $r$ & z & Q & Q & Q & $\underline{z}$ & Q \\
\hline \multirow{5}{*}{ 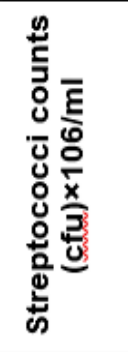 } & \multirow{5}{*}{ 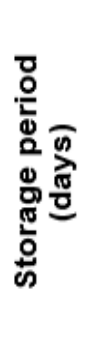 } & $\stackrel{N}{ }$ & ส & స్ల & F & \& & ถి & $\bar{\sigma}$ \\
\hline & & $\sigma$ & $\bar{m}$ & $q$ & q & $\overline{6}$ & $\stackrel{\infty}{\bullet}$ & R \\
\hline & & 0 & ร & [5 & in & ธิ & $\stackrel{2}{2}$ & 尺 \\
\hline & & m & กิ & $\bar{\sigma}$ & $\hat{0}$ & $\stackrel{\infty}{\wedge}$ & $\mathbb{\infty}$ & œ \\
\hline & & $r$ & లి & \& & in & : & $\Sigma$ & ๗ \\
\hline \multirow{5}{*}{ 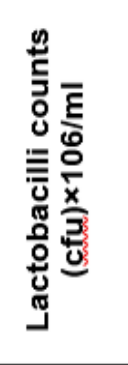 } & \multirow{5}{*}{ 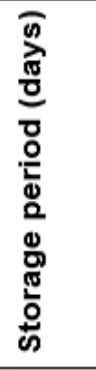 } & $\stackrel{ }{ }$ & $\hat{N}$ & స్ల & $F$ & $\stackrel{\infty}{q}$ & ถి & 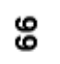 \\
\hline & & 0 & శ్లి & g & 吕 & 용 & $\stackrel{\infty}{\bullet}$ & $\bar{\kappa}$ \\
\hline & & 0 & f & 吕 & I & R & $\stackrel{2}{\wedge}$ & Ф \\
\hline & & $m$ & న & छ & $\stackrel{2}{2}$ & $\bar{\infty}$ & ळ & $\stackrel{\infty}{\curvearrowleft}$ \\
\hline & & $r$ & $\overline{7}$ & ธ్ర & 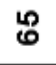 & N & ळ & ภ \\
\hline \multirow{5}{*}{ 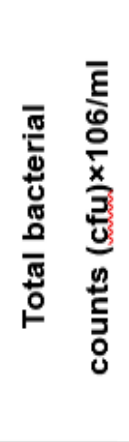 } & \multirow{5}{*}{ 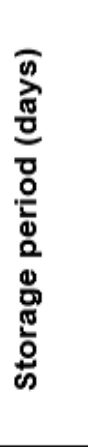 } & $\stackrel{N}{ }$ & q & ¿ & ప & $\stackrel{\circ}{\circ}$ & $\stackrel{g}{\rightleftarrows}$ & స̃ \\
\hline & & 0 & 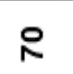 & $\stackrel{\infty}{\infty}$ & $\stackrel{2}{\circ}$ & ్ి & $\stackrel{\text { mे }}{\square}$ & g \\
\hline & & 0 & $\stackrel{\circ}{\circ}$ & $\stackrel{\circ}{\doteqdot}$ & స్ & $\stackrel{m}{=}$ & $\stackrel{\varrho}{\ddagger}$ & $\stackrel{\text { L }}{\sim}$ \\
\hline & & $m$ & $\stackrel{\leftrightarrow}{\circ}$ & ్ָల్ & $\underset{z}{J}$ & $\stackrel{\mathscr{Q}}{\sim}$ & $\stackrel{\vdots}{\leftarrow}$ & $\stackrel{乛}{\leftarrow}$ \\
\hline & & $r$ & $\stackrel{\circ}{\circ}$ & $\underset{\text { స్ }}{ }$ & $\stackrel{ \pm}{\text { m }}$ & ₹ & مִ & $\stackrel{\varrho}{\circ}$ \\
\hline \multirow{5}{*}{ 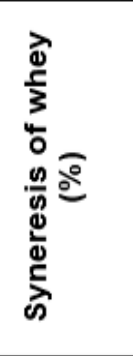 } & \multirow{5}{*}{ 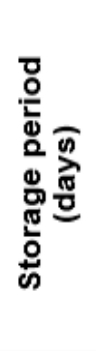 } & $\stackrel{\text { N }}{2}$ & $\bar{n}$ & $\stackrel{\infty}{\sim}$ & $\stackrel{\mathscr{N}}{ }$ & $\stackrel{\text { N }}{ }$ & กิ & $\stackrel{\text { N }}{ }$ \\
\hline & & 0 & ని & $\stackrel{\text { N }}{2}$ & $\mathbb{N}$ & ส & $\stackrel{\infty}{\sim}$ & $\stackrel{\circ}{\circ}$ \\
\hline & & 0 & $\stackrel{\text { N }}{ }$ & $\stackrel{\mathscr{N}}{ }$ & N & $\bar{N}$ & $\stackrel{\circ}{\circ}$ & $\stackrel{m}{=}$ \\
\hline & & n & ని & $\stackrel{\text { ஸొ }}{2}$ & $\stackrel{N}{\circ}$ & $\stackrel{\sim}{N}$ & $\stackrel{\infty}{=}$ & $\stackrel{6}{\circ}$ \\
\hline & & $r$ & న్ల & $\bar{m}$ & ळे & $\stackrel{\mathscr{N}}{ }$ & กิ & 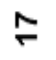 \\
\hline \multicolumn{2}{|l|}{ 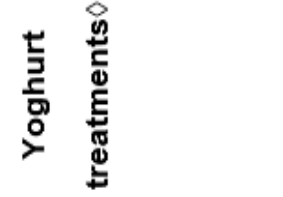 } & & "ul & $F$ & 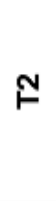 & $\stackrel{p}{q}$ & 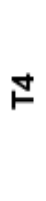 & $\stackrel{\circ}{\llcorner}$ \\
\hline
\end{tabular}


K. M. K. Kebary, et al.,

\begin{tabular}{|c|c|c|c|c|c|c|c|c|}
\hline \multirow{5}{*}{ 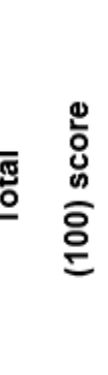 } & \multirow{5}{*}{ 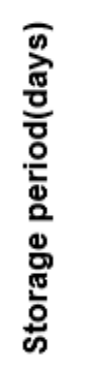 } & $\stackrel{N}{\leftarrow}$ & ஐ & ฌ & Ш & ฌ & ৪ & ஐ \\
\hline & & $\sigma$ & $\tilde{\infty}$ & 吅 & ஓ & ชั & б & ৪ \\
\hline & & $\bullet$ & $\hat{\infty}$ & $\underset{\infty}{\infty}$ & ஐ & ชั & హু & \%ু \\
\hline & & $m$ & 沛 & ֻ & Б & ช & హ' & ু \\
\hline & & - & $\widehat{\infty}$ & జ & ஹ & ৪ & นั & ' \\
\hline \multirow{5}{*}{ 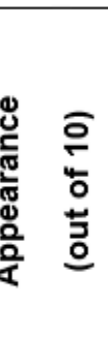 } & \multirow{5}{*}{ 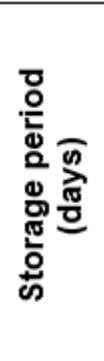 } & $\cong$ & $\sim$ & 0 & $\sim$ & $\infty$ & $N$ & $r$ \\
\hline & & $\sigma$ & $\infty$ & $\infty$ & $\infty$ & $\sigma$ & $\infty$ & $\infty$ \\
\hline & & $\bullet$ & $\infty$ & $\infty$ & 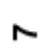 & $\sigma$ & $\sigma$ & $\sigma$ \\
\hline & & $m$ & $\infty$ & $\infty$ & $\infty$ & $\sigma$ & $\sigma$ & 0 \\
\hline & & - & $\infty$ & $\infty$ & $\infty$ & $\sigma$ & $\sigma$ & $\sigma$ \\
\hline \multirow{5}{*}{$\begin{array}{l}\text { 음 } \\
\text { 호 } \\
\text { 픙 }\end{array}$} & \multirow{5}{*}{ 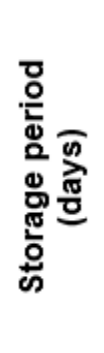 } & & $r$ & N & $\sim$ & $\infty$ & $\infty$ & $\infty$ \\
\hline & & $\sigma$ & $\infty$ & $\infty$ & $\infty$ & $\sigma$ & $\infty$ & $\infty$ \\
\hline & & 0 & $\infty$ & $\infty$ & $\infty$ & a & $\infty$ & $\infty$ \\
\hline & & $m$ & $\infty$ & $\infty$ & $\sigma$ & ( & $\infty$ & $\infty$ \\
\hline & & - & $\infty$ & $\infty$ & a & 0 & の & 0 \\
\hline \multirow{5}{*}{ 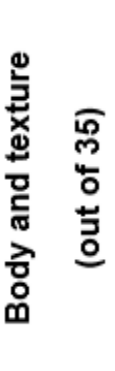 } & \multirow{5}{*}{ 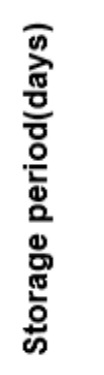 } & $\stackrel{\Upsilon}{\leftarrow}$ & ి & $\bar{m}$ & ి્ల & $\bar{m}$ & న్ల & స్లా \\
\hline & & $\sigma$ & $\bar{m}$ & ా & $\bar{m}$ & స్ల & స్ల & స్లా \\
\hline & & $\bullet$ & ా & 이 & ह & స్ల & ల్ల & ల్ల \\
\hline & & $m$ & $\bar{m}$ & $\bar{m}$ & స్ల & స్ల & ల్ల & से \\
\hline & & - & ి્ల & స్ల & స్ల & $\bar{m}$ & से & से \\
\hline \multirow{5}{*}{ 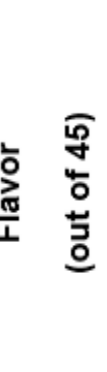 } & \multirow{5}{*}{ 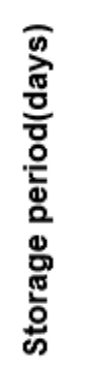 } & $\stackrel{\Upsilon}{\sim}$ & 웅 & \& & ㅇ & พั & $\mathscr{q}$ & ษ \\
\hline & & $\sigma$ & ㅇ & Y & พ & พ & ? & พ \\
\hline & & $\bullet$ & 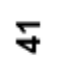 & พ & พั & พ & J & ? \\
\hline & & $m$ & $\overline{8}$ & 寸 & Y & พ & J & ? \\
\hline & & - & $\bar{y}$ & 웅 & g & \& & ? & พ \\
\hline \multicolumn{2}{|c|}{ 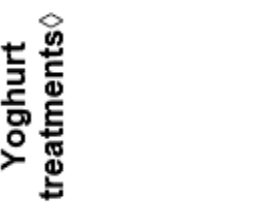 } & & ${ }^{*} u$ & $F$ & $\mathfrak{N}$ & $m$ & $\mathbb{F}$ & $\stackrel{2}{\models}$ \\
\hline
\end{tabular}




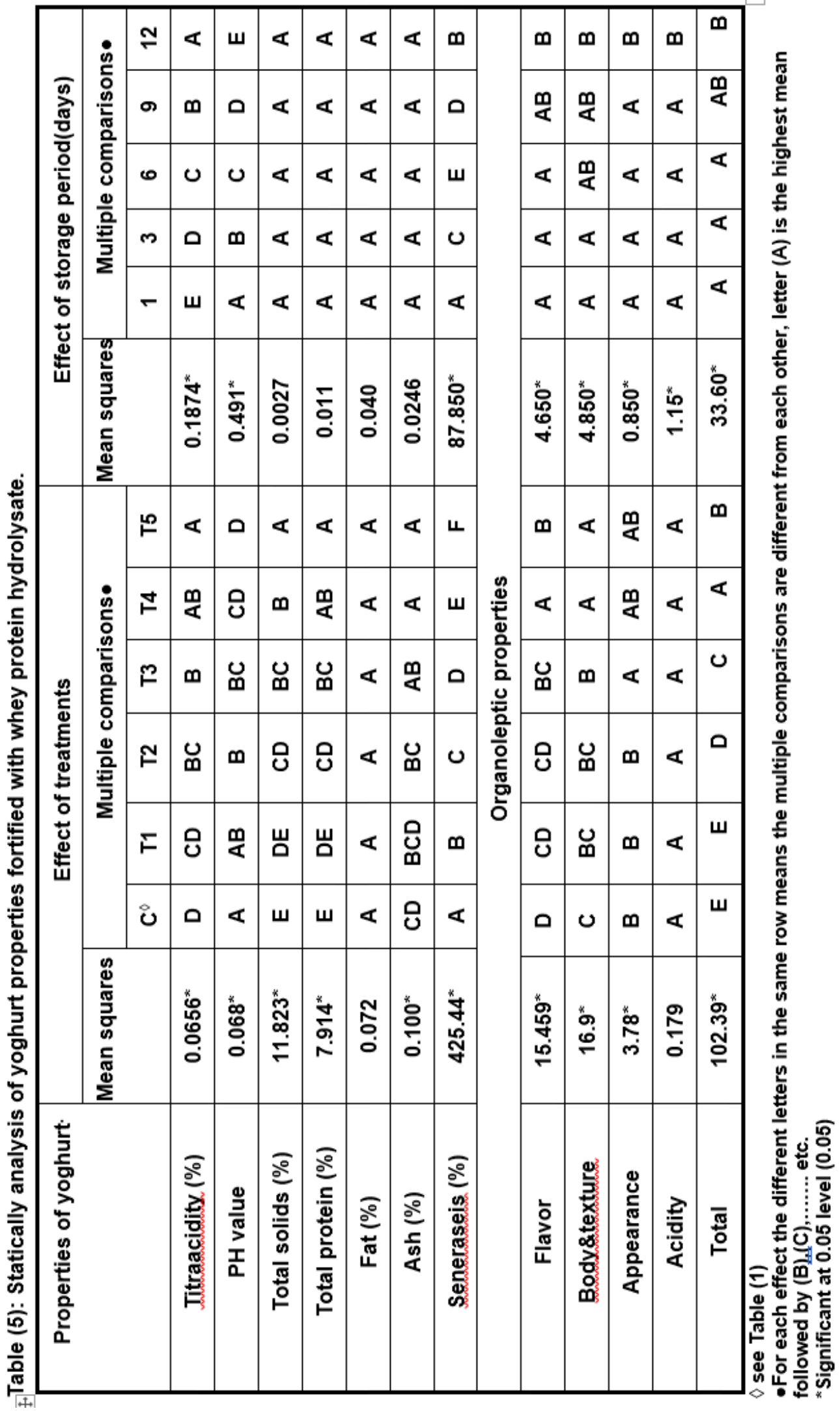


It could be concluded that fortifying of cow's milk with whey proteins increased the titratable acidity, total solids and total protein content of the resultant yoghurt treatments, while decreased the $\mathrm{pH}$ values and the whey syneresis. Also, adding the whey protein hydrolysate up to $2.0 \%$ increased the scores of organoleptic properties therefore it is possible to make good quality yoghurt by adding whey protein hydrolysate up to $2.0 \%$.

\section{REFERNCES}

A. O. A. C. (2012). Official Method of Analysis of Association of Chemists. $19^{\text {th }}$ Ed. Published by Assiociation of Official Agriculture Chemists, Washington. D. C. (USA).

Al-Aswad, Sara, A. Helal, S. M. Shamsia and S. Awad (2018). Quality and rheological properties of sweetened yoghurt and bio-yoghurt enriched with pomegranate juice. Egyptian J. Dairy Sci., 46:41-50.

Ali, M. M. E., K. M. K. Kebary, K. A. Shaheen and Maally B. M. Abo Bakr (2014). Quality of yoghurt made from cow's milk supplemented with whey proteins. Menoufia J. Agric. Res., 39: 1815-1828.

Ayar, A., D. Sert, H. Kalyonku and F. Yazici (2006). Physical, chemical, nutritional and organoleptic characteristics of fruit added yogurts. J. Food Technol., 4: 44-49.

Aziznia, S., A. Khosrowshahi, A. Madadlou and J. Rahimi (2008). Whey protein concentrate and gum tragacanth as fat replacers in nonfat yogurt: chemical, physical, and microstructural properties. J. Dairy Sci., 91: 2545-2552.

Badawi, R. M., A. Hamed, K. M. K. Kebary and Hweda A. El-Sayed (2008). Effect of replacing milk fat with fat replacers on the quality of stirred yoghurt. Egyptian J. Dairy Sci., 36: 197-206.
Bierzuńska, P. and D. Sokolińska (2018). Determination of antioxidant activity of yoghurt enriched with polymerized whey protein. Mljekarstvo, 68:272-281.

Birollo, G. A., J. A. Reinheimer and C. G. Vinderola (2000). Viability of lactic acid microflora in different types of yoghurt. Food Res. Int., 33: 799-805.

Blassy, Kholoud, I and A. M. Abdeldaiem (2018). Preparation and properties of buffalo milk yoghurt fortified with some healthy additives. Egyptian $\mathrm{J}$. Dairy Sci., 46:51-65.

Bourne, M. C. and A. S. Szczesniak (2003). Sensory evaluation-texture. In: Caballero B, Trugo L, Finglas $\mathbf{P}$ (Eds.): Encyclopedia of Food Sciences and Nutrition, Academic Press, Amsterdam, the Netherlands, pp. 5167 - 5174.

Chandan, R. C., C. H. White, A. Kilara and Y. H. Hui (2006). Manufacturing of yogurt and fermented milks. $1^{\text {st }}$ edition, Blackwell Publishing Professional, Ames, lowa, pages 151-265.

Danneberg, F. and H. G. Kessler (1988). Effect of denaturation of $B$ lactoglubulin on texture properties of set-style nonfat yoghurt. 1.syneresis. Michwissenschaft, 43: 632-635.

De Man, J. C., M. Rogosa and M. E. Sharpe (1960). Amedium for the cultivation of lactobacilli. J. Appl. Bacteriol, 23(1): 130-135.

Delikanli, B. and T. Ozcan (2014). Effects of various whey proteins on the physicochemical and textural properties of set type nonfat yoghurt. Int. J. Dairy Technol., 67:495-503.

Difco Manual (1953). Dehydated culture media and reagents $9^{\text {th }}$ ed. Difcolabortories, Detriot, Michigan.

ElKot, W. F. (2017). Preparation and properties of yoghurt using Jerusalem artichoke tubers powder and different probiotic strains. Egyptian J. Dairy Sci., 45: 55-66. 
Fox, P. F., P. T. Guinee, M. T. Cogan and P. L. H. McSweeney (2017).

Fundamentals of Cheese Science, $2^{\text {th }}$ Ed. Published by Springer Nature, New York, pp. 523 - 524.

Gaudreau, H., C. P. Champagne, G. Remondetto, L. Bazinet and $M$. Subirade (2013). Effect of catechins on the growth of oxygen-sensitive probiotic bacteria. Food Res. Int., 53: 751-757.

Ghanimah, M. A. (2018). Functional and technological aspects of whey powder and whey protein products. Int. J. Dairy Technol., 71: 454-459.

Guggisberg, D., P. Eberhard and B. Albrecht (2007). Rheological characterization of set yogurt produced with additives of native whey proteins. Int. Dairy J., 17: 1353-1359.

Hamed, A. I., K. M. K. Kebary, R. M. Badawi and Nevein S. Omar (2010). Manufacture of low fat prebiotic yoghurt. Menoufia J. Agric. Res., 35: 157-174.

Jeewanthi, R. K. C., N. Lee and H. Paik (2015). Improved functional characteristics of whey protein hydrolysates in food industry. Korean J. Food Sci. Animal Resources, 35: 350-359.

Kailasapathy, K. and D. Supriadi (1996). Effect of whey protein concentrate on the survival of Lactobacillus acidophilus in lactose hydrolyzed yogurt during refrigerated storage. Milchwissenschaft, 51: 566-569.

Kamaly, K. M., K. M. K. Kebary, A. H. ElSonbaty and Khadiga R. M. Badawi (2011). Effect of fortification ingredients on the quality of yoghurt made from cow's milk. Menoufia $\mathbf{J}$. Agric. Res., 36: 1591-1609.

Kebary, K. M. K. and S. A. Hussein (1999). Improving viability of bifidobacteria by microentrapment and their effect on some pathogenic bacteria in stirred yoghurt. J. Dairy Sci. and Technol., 28: 113-131.

Kebary, K. M. K., R. M. Badawy, A. I. Hamed and Nevein S. Omar (2010). preparation and properties of novel functional yoghurt from bufflo milk. Proc. $11^{\text {th }}$ Egyptian Conf. Dairy Sci., Technol., pp. 463-478.

Kebary, K. M. K., A. H. El-Sonbaty, K. M. Kamaly and Khadega R. M. Badawi (2012). Effect of using normal and roby strains of yoghurt starter in the manufacture of yoghurt from cow's milk fortified with different levels of inulin and non-fat dried milk. Egyptian J. Dairy Sci., 40: 99-111.

Khalil, R. A. M. and Kholoud I. Blassy (2017). Preparation and properties of free fat yoghurt supplemented with oat and flavoured with pomegranate juice and soursop pulp. Egyptian J. Dairy Sci., 45:143-154.

Landge, V. L. (2009). Quality of yogurt supplemented with whey protein concentrate and effects of whey protein denaturation. Master's Thesis. Faculty of Food Sciences, Kansas State University, Manhattan, Kansas.

Ling, A. R. (1963). A Text Book of Dairy Chemistry, Vol. 2 Practical $3^{\text {th }}$ ed. Chapman and Hall, Ltd., London.

Marth, E. H. (1978). Standard methods for the examination of dairy products, $14^{\text {th }}$ ed. Am. Buble. Health Assoc. Washington, DC.

Megenis, B. R., E. S. Prudencio, R.D.M.C. Amboni, N. G. Cerquierra Jr., R. V. B. Olivierra, V. Soldi and H. D. Benedet (2006). Compositional and physical properties of yogurt manufactured from whey and cheese concentrated by ultrafiltration. Int. J. Food Sci. Technol., 41: 560-568.

Mehriz, A. M., M. N. A. Hassan, A. A. Hefny and A. H. Aziz (1993). Manufacture and some properties of ABT cultured and 
sweet acidophilus milks. Egyptian J. Dairy Sci., 21:259-272.

Muniandy, P., A. B. Shori and A. S. Baba (2016). Influence of green, white and black tea addition on the antioxidant activity of probiotic yogurt during refrigerated storage. Food Packaging and Shelf Life, 8: 1-8.

Pintro, P. T. M., L. Rabiey, G. Robitaille and M. Britten (2011). Use of modified whey protein in yoghurt formulations. Int. Dairy J., 21:21-26.

Priyadarshani, W. M. D. and M. A. M. R. Muthumuniarachchi (2018). Physicochemical and sensory quality of mung bean (Vigna radiata) enriched stirred yoghurt. Int. Food Res. J., 25: 20512055.

Shah, N.P. (2007). Functional cultures and health benefits. Int. Dairy J., 17: 12621277.

Shamsia, S. M. (2010). Forification of standardized buffalo milk yoghurt with calcium citrate and whey protein concentrate. J. Agric. and Env. Sci. Damanhour. Univ., Egypt .9: 25-35.

Singh, G. (2007). Calcium lactate fortification of reduced fat yoghurt and fortification of "simulated yoghurt gel " with partially hydrolyzed whey protein. THESIS M. S. C. Master of Science Major in Biological Sciences Food and Biomaterials Processing Specialization South Dakota State University.
Skinner, F. A. and L. B. Quesnel (1978). Streptococci. Academic press, New York, P 390.

Sodini, I., J. Montella and P. S. Tong (2005). Physical properties of yogurt fortified with various commercial whey protein concentrates. J. Sci. Food Agri., 85: 853-859.

Steel, R. G. D. and J. H. Torrie (1980). Principles and Procedures of Statistics. A biometrical approach. ${ }^{2 \text { th }}$ Ed. McGraw-Hill Book Co., New York.

Unal, G. and Akalin (2013). Influence of fortification with sodium-calcium caseinate and whey protein concentrate on microbiological, textural and sensory properties of settype yoghurt. Int. J. Dairy Technol., 66: 264-272.

Wang, C., F. Gao, T. Zhang, Y. Wang and M. Guo (2015). Physiochemical, textural, sensory properties and probiotic survivability of Chinese Laosuan Nai (protein-fortified set yoghurt) using polymerised whey protein as a co-thickening agent. Int. J. Dairy Technol., 68: 261-270.

Zhao, D. and N. P. Shah (2014). Influence of tea extract supplementation on bifidobacteria during soymilk fermentation. Int. J. Food Microbiol., 188: 36-44. 
تأثير تدعيم اللبن البقري ببروتينات الشرش المتحللة على صفات اليوجورت

خميس محمد كامل كعباري، سامي عبدالرحمن حسين، رجب محمد بدوي،

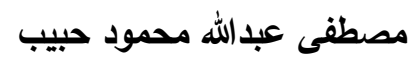

قسم علوم وتكنولوجيا الألبان -كلية الزراعة -جامعة المنوفية شبين الكوم جمهورية مصر العربية

الملخص العربي

يحتوي الثرش الناتج من صناعة الجبن على حوالي · r\% من البروتينات ولقد بذلت جهود كبيرة لفصل هذا البروتين

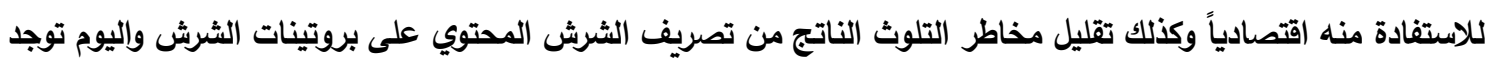
منتجات عديدة من الثرش وبروتينات الثرش تستخدم في كثير من الصناعات منها تدعيم منتجات الألبان وذلك للاستفادة

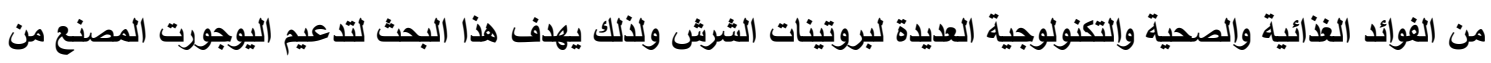

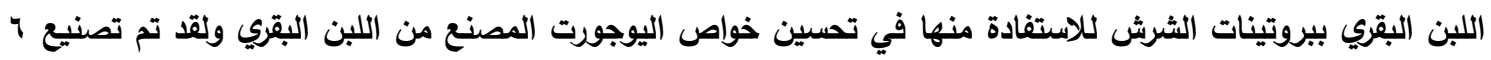

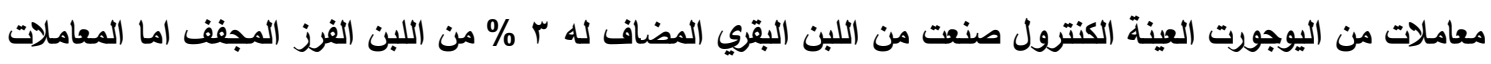

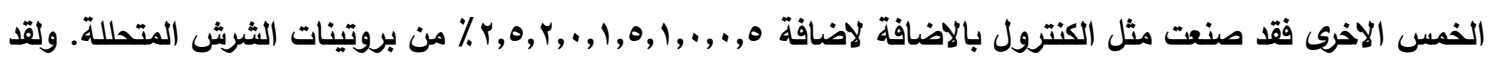

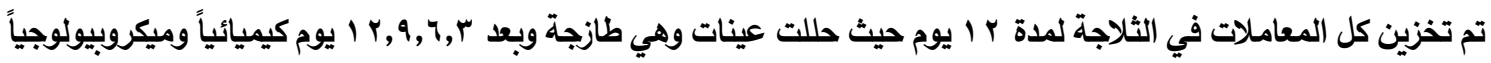
وريولوجياً وكنلك التقييم الحسي ولقد أوضحت النتائج المتحصل عليها بعد تحليلها احصائياً ما يلي: ا - أدى إضافة بروتينات الثرش المتحللة لزيادة نسب كل من الحموضة والجوامد الصلبة الكلية والبروتين الكلي والرماد في حين لم تؤثر على نسبة الدهن.

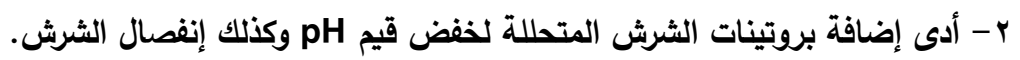

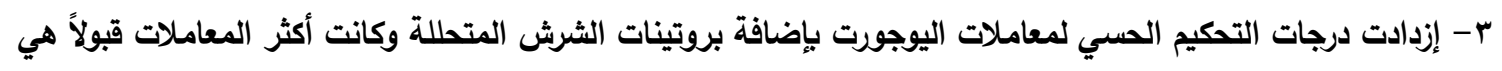

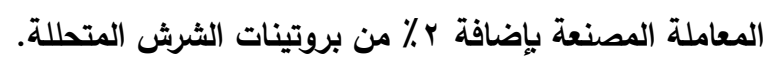

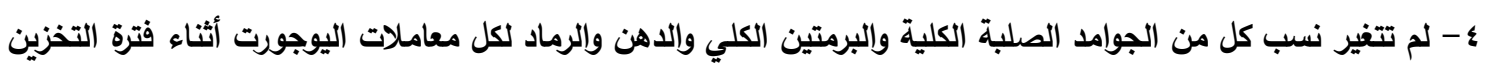

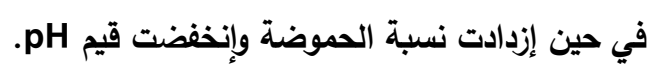
ه- إنخفضت نسب إنفصال الثرش أثناء الأيام الست الأولى من التخزين ثم إزدادت تدريجياً بعد ذلك حتى نهاية فترة التخزين. 4- لم تتغير درجات التحكيم لكل معاملات اليوجورت معنوياً أثناء التخزين لمدة 9 أيام ثم إنخفضت قليلاً بعد ذلك. 
K. M. K. Kebary, et al., 